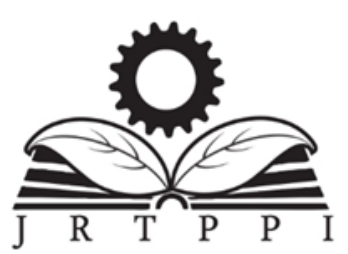

Vol. 11 No. 1 (2020) 19-26

Jurnal Riset

Teknologi Pencegahan Pencemaran Industri

Kementerian

Perindustrian

REPUBLIK INDONESIA

Journal homepage : http://www.jrtppi.id

\title{
Evaluating the Performance of Three Chambers Microbial Salinity Cell (MSC) Subjected to Different Substrate Concentrations to Accomplish Simultaneous Organic and Salt Removal in The Wastewater
}

\author{
Rustiana Yuliasni ${ }^{1 *}$, Nur Zen ${ }^{1}$, Nanik Indah Setianingsih ${ }^{1}$ \\ ${ }^{1}$ The Centre of Industrial Pollution Prevention Technology, Jalan Ki Mangunsarkoro No. 6, Semarang, Central Java
}

\begin{tabular}{|c|c|}
\hline A R T IC LE I N F O & A B S T R A C T \\
\hline $\begin{array}{l}\text { Article history: } \\
\text { Received } 20 \text { March } 2020 \\
\text { Received in revised form } 20 \text { April } 2020 \\
\text { Accepted } 27 \text { April } 2020 \\
\text { Available online } 21 \text { May } 2020\end{array}$ & $\begin{array}{l}\text { This study aimed to identify the effect of substrate concentration on the performance of a } \\
\text { three chambers Microbial Salinity Cell (a three chambers MSC). In this study, a three } \\
\text { chambers MSC were made from plexiglass with total volume of } 200 \mathrm{ml} \text {. An aluminium } \\
\text { wrapped with platinum on vulcan carbon cloth was used as electrodes, with each working } \\
\text { area of } 63 \mathrm{~cm}^{2} \text {. The result showed that a three chambers MSC was able to generate electricity } \\
\text { and at the same time removed the salinity. The degree of electricity generation and salinity }\end{array}$ \\
\hline $\begin{array}{l}\text { Keywords: } \\
\text { Microbial Salinity Cell } \\
\text { three chambers MSC } \\
\text { Microbial Fuel Cell } \\
\text { electricity generation } \\
\text { salinity removal }\end{array}$ & $\begin{array}{l}\text { removal was influenced by initial substrate concentration in the anode chamber. The higher } \\
\text { substrate concentration, the better performance of the MSC. The best performance of the } \\
\text { MSC was achieved when the initial substrate was } 2034 \mathrm{mg} / \mathrm{L} \text { as COD, lead to a maximum } \\
\text { voltage of } 0.44 \mathrm{~V} \text {, and maximum current density of } 0.29 \mathrm{~mA} / \mathrm{m}^{2} \text {. With } \% \text { CE was } 5.4 \% \text {. The } \\
\text { maximum conductivity upsurge in salinity chamber was from } 11.2 \mu \mathrm{S} / \mathrm{cm} \text { to } 1027 \mu \mathrm{S} / \mathrm{cm} \\
\text { (corresponding to salinity of } 0.57 \% \mathrm{ppt} \text { ). }\end{array}$ \\
\hline
\end{tabular}

\section{INTRODUCTION}

The fish processing industry generates liquid wastewater contains high organic matter and salinity (Lefebvre \& Moletta, 2006). The conventional biological treatment is used to treat this type of wastewater (Aloui, Khoufi, Loukil, \& Sayadi, 2009). However, some issues, such as high salinity, hindered the performance of the conventional technology. In order to treat and at the same time to utilized this wastewater into more sustainable way, the microbial salinity cell was introduced. The objective of this technology was to simultaneously remove organic material and to convert it into electricity and to remove salt in the wastewater. The similar mechanisms, Microbial Desalination Cell (MDC), also can harvest electricity and perform desalination at the same time (Gude, 2016; Kim \& Logan, 2013; Lefebvre, Tan, Kharkwal, \& Ng, 2012; Mehanna, Kiely, Call, \& Logan, 2010). However, MDC can only be used for drinking water desalination, not for real high salinity wastewater. Therefore, for more applicable technology to treat high salinity wastewater, microbial salinity cell (MSC) system concept was introduced.

A Microbial Salinity Cell (MSC) system consists of three chambers, which are anode, salinity and cathode chamber. Between anode and salinity chamber, cation exchange membrane (CEM) is installed, and between salinity and cathode chamber, anion exchange membrane is installed. Anode chamber is filled with a high salinity

\footnotetext{
${ }^{*}$ Correspondence author. Tel. : +6281288581633

E-mail :rustianay@kemenperin.go.id
} 
substrate. When biofilm oxidize the substrate, the proton will drift to the salinity chamber, and the electron will transfer to the external circuit (producing currents). While in the cathode, negative ions will drift into the salinity chamber. The flow of ions will increase the conductivity in the salinity chamber.

This study aimed to identify the effect of substrate concentration on the performance of a Three chambers Microbial Salinity Cell (a three chambers MSC), using synthetic wastewater containing glucose.

\section{METHODS}

\subsection{Reactor Configuration}

A three chambers MFC system was built, consisting of anode, salinity chamber and cathode chamber (as shown in Figure 1). Each chamber was made of plexy glass bottle filled with solution of $200 \mathrm{ml}$. Both anode and cathode were made of aluminum wrapped with platinum on vulcan carbon cloth (fuellcellstore.com, USA). The anode had a working area of $63 \mathrm{~cm}^{2}$. A Cation Exchange Membrane (CEM) (Nafion 117, Chemours, USA) was attached to separate anode and salinity chamber. An Anion Exchange Membrane (AEM) (Fumasep FAS-30, Fuma-tech, USA) was installed to separate salinity and cathode chamber. Platinum wires were mounted in the electrodes, used as current collectors. Temperature in the anode chamber was maintained at $37^{\circ} \mathrm{C}$ using hot plate. The cathode chamber was continuously sparged with oxygen.

\subsection{Inoculum and substrate}

Inoculums were a mix cultures, generated from inactive Aerobic Granular Sludge (AGS) (Figure 2). Selective Pressure mechanism was done to ensure that mixed culture was dominated by Geobacter sulfurreducens species by doing inoculation in a sealed bottle with growth medium for specific Geobacter sulfurreducens (DSMZ medium No. 826, Germany) for 73 hours. The growth of the inoculum was monitored using Optical Density (OD 600) methods (Figure 2).
Anolyte was made of a mixture of substrate (glucose), $40 \mathrm{ml}$ seed mix microorganisms, $140 \mathrm{ml}$ Geobacter sulfurreducens (DSMZ medium No. 826, Germany), $10 \mathrm{ml}$ trace element and $10 \mathrm{ml}$ vitamin (which both referred to DSMZ medium 141, Germany). The addition of glucose was varied, the first phase was $201 \mathrm{mg} / \mathrm{L}$ (as COD) and the second phase was $2034 \mathrm{mg} / \mathrm{L}$ (as COD). Salinity (middle) chamber was filled with $200 \mathrm{ml}$ demineralized water. Catholyte was consisted of $200 \mathrm{ml}$ of phosphate buffer $(50 \mathrm{mM})$.

\subsection{Operational Condition}

The Microbial Salinity Cell (MSC) was operated using glucose as substrate, with two different concentrations: $201.2 \mathrm{mg} / \mathrm{L}$ (known as $1^{\text {st }}$ stage) and 2034 $\mathrm{mg} / \mathrm{L}$ (known as $2^{\text {nd }}$ stage), analysed as COD. In the first stage, $201.2 \mathrm{mg} / \mathrm{L}$ glucose was used as substrate. Initial conductivity in the anode chamber was $15.09 \mathrm{mS} / \mathrm{cm}$ and the experiment was run for 6 days. In the second stage, after the MSC solution from the first stage was emptied, anode chamber was filled with new glucose-medium with a concentration of $2034 \mathrm{mg} / \mathrm{L}$, salinity was $11 \mathrm{mS} / \mathrm{cm}$ and the experiment was run for 7 days. The MSC experiment was run as batch mode. During the experiment, the salinity increase was monitored in the salinity chamber along with the current and voltage.

\subsection{Analysis and Calculation}

The current dan voltage was observed using a potentiostat (Digi-IVY, Model DY 2023) or sometimes using a voltmeter (Hantek, 365), and recorded for every 100 s. The COD was measured using standard methods and the conductivity was measured using a conductivity meter (TES-1381). The optical density (OD) 600 was measured by scanning absorbance using a spectrophotometer at $600 \mathrm{~nm}$.

Coulombic Efficiency (\%CE) is defined as the fraction of electrons transferred to the anode among the total electron, released by substrate oxidation. \%CE was calculated as in (Min \& Logan, 2004). Salinity has derived by converting the conductivity value into salinity (ppt). 

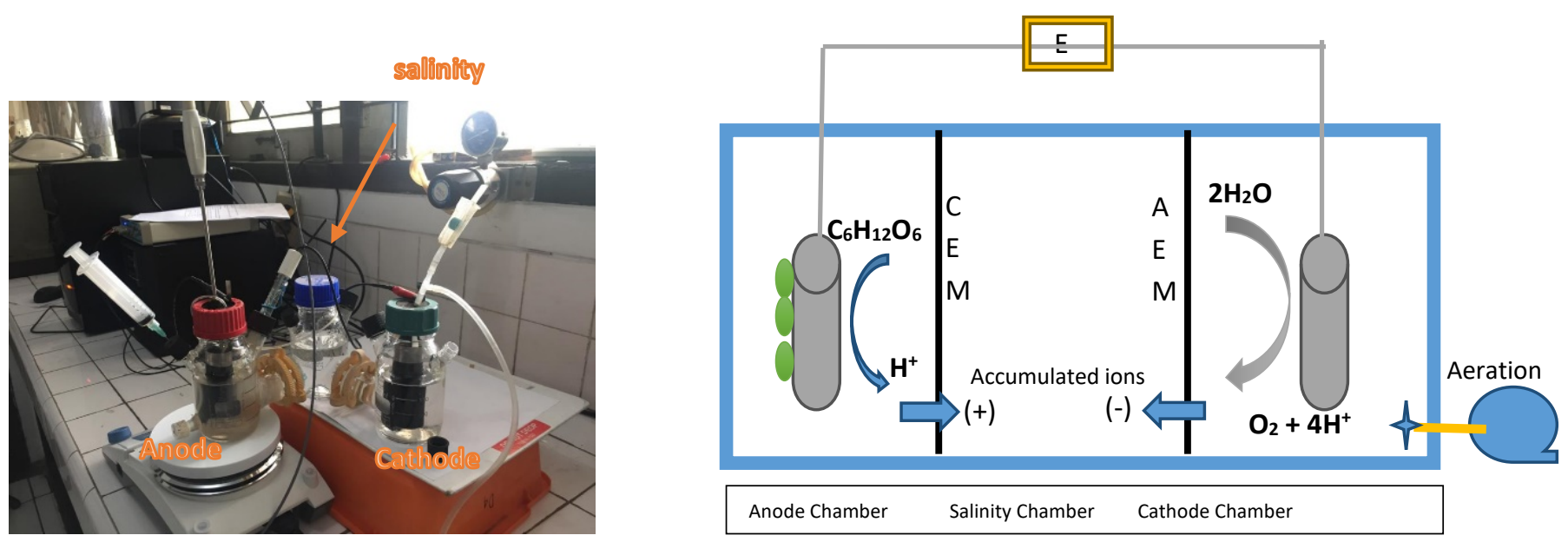

Figure 1. A reactor three chambers MSC (left) MSC scheme (right)
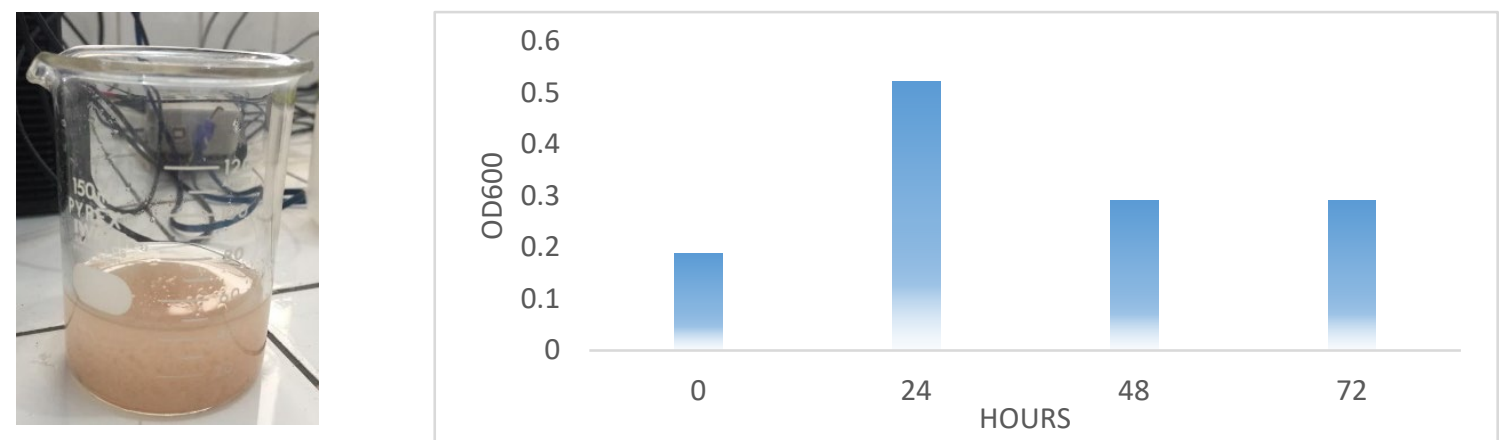

Figure 2. Inactive Aerobic Granular Sludge seed (left). Optical density of inoculum (at $72 \mathrm{~h}$ ) before added to the MSC system (right).

\section{RESULT AND DISCUSSION}

\subsection{MSC performance as a function of electricity generation: voltage and current response}

In the first stage period, $201.2 \mathrm{mg} / \mathrm{L}$ glucose (concentration analysed as COD) was used as substrate. Initial conductivity in the anode chamber was $15.09 \mathrm{mS} / \mathrm{cm}$ and the experiment lasted for 5 days. The currents were recorded for every $100 \mathrm{~s}$ continuously for 6 days using a potentiometer (data were not shown), while voltage could only be recorded for 1 hour maximum because of technical limitation. The voltage profile only be recorded on day 1 and could not be recorded at day 6 because of the technical error from voltmeter, but judging from the currents data which did not show variation significantly, it also can be concluded that voltage will also do not variate significantly because normally currents were responded accordingly to voltage.

However, the Coulombic Efficiency (\%CE) still can be calculated in this stage. Figure 3 shows the profile of voltage versus current density. Figure 3 shows that at the beginning, the voltage was $0.283 \mathrm{~V}$ and then dropped to $0.135 \mathrm{~V}$ while the currents could drop until $1.56 \times 10^{-4}$ $\mathrm{mA} / \mathrm{m}^{2}$ but increase again for maximum $4.5 \times 10^{-4} \mathrm{~mA} / \mathrm{m}^{2}$. The graph pattern (only for currents) keep repeated during 6 days observation using a potentiostat (data are not shown). And the maximum current density achieved during stage 1 was $4.5 \times 10^{-4} \mathrm{~mA} / \mathrm{m}^{2}$, while the maximum voltage was $0.283 \mathrm{~V}$. According to theoretical calculation using glucose as substrate, the maximum voltage reached in the system was $1.14 \mathrm{~V}$, thus in order to achieve the desirable voltage or current for practical purposes, the MSC should be stacked 
(Aelterman, Rabaey, The Pham, Boon, \& Verstraete, 2006). Compared to the theoretical calculation, the voltage and current produced in this study were still low, because of the wide distance between anode and cathode creates high over-potential of the system which inhibits the flows of the electron from anode to cathode (Fan, Hu, \& Liu, 2007). Moreover, the low generation of both voltage and current ( from Figure 3,4, and 5) can be also because of the energy that comes from the oxidation of glucose is used to drive the ions into salinity chamber rather than to produce electricity, the similar mechanism that also occurs in MDC system (Chen, Liang, Wei, Zhang, \& Huang, 2012). To boost the capability of the anode to capture the electron from the system, polarization should be done. Unfortunately, because of the limitation of potentiostat model device, polarization was not possible to be done.

In the second stage, after the MSC solution from the first stage emptied, anode chamber was filled with new glucose-medium with concentration $2034 \mathrm{mg} / \mathrm{L}$ as COD, salinity was $11 \mathrm{mS} / \mathrm{cm}$ and experiment was run for 7 days. Because of the limitation ability of potentiometer to simultaneously measure current and voltage, for measuring voltage, another portable voltmeter was used (Hantex). Currents were continuously recorded for every 100 seconds, from day 1 to day 7 using a potentiometer (data are not all shown here). However, because the voltmeter could not observe currents for 24 hours continuously, the voltage was measured only for 1 hour at the beginning (day 1) and the ending of the cycle (day 7). Therefore, the data presented in Figure 4 and Figure 5 were data from day 1 and day 7 and only were measured for 1 hour, so that we could get a correlation between current and voltage.

Stage 2, with substrate concentration $2034 \mathrm{mg} / \mathrm{L}$, at day 1 observation, the initial voltage was higher than at first stage. The maximum voltage was $0.44 \mathrm{~V}$, with corresponding current density was $3.9 \times 10^{-4} \mathrm{~mA} / \mathrm{m}^{2}$. However, the voltage then dropped at day 7 to a minimum of 0.15 but then raised again to $0.23 \mathrm{~V}$, with corresponding current density was $0.29 \mathrm{~mA} / \mathrm{m}^{2}$. The average voltage during stage 2 was about 0.2 to $0.44 \mathrm{~V}$, and the maximum current density was $0.29 \mathrm{~mA} / \mathrm{m}^{2}$ (in which $1000 \mathrm{x}$ higher than first stage). The rise of the current density and voltage was explainable, due to higher substrate concentration.

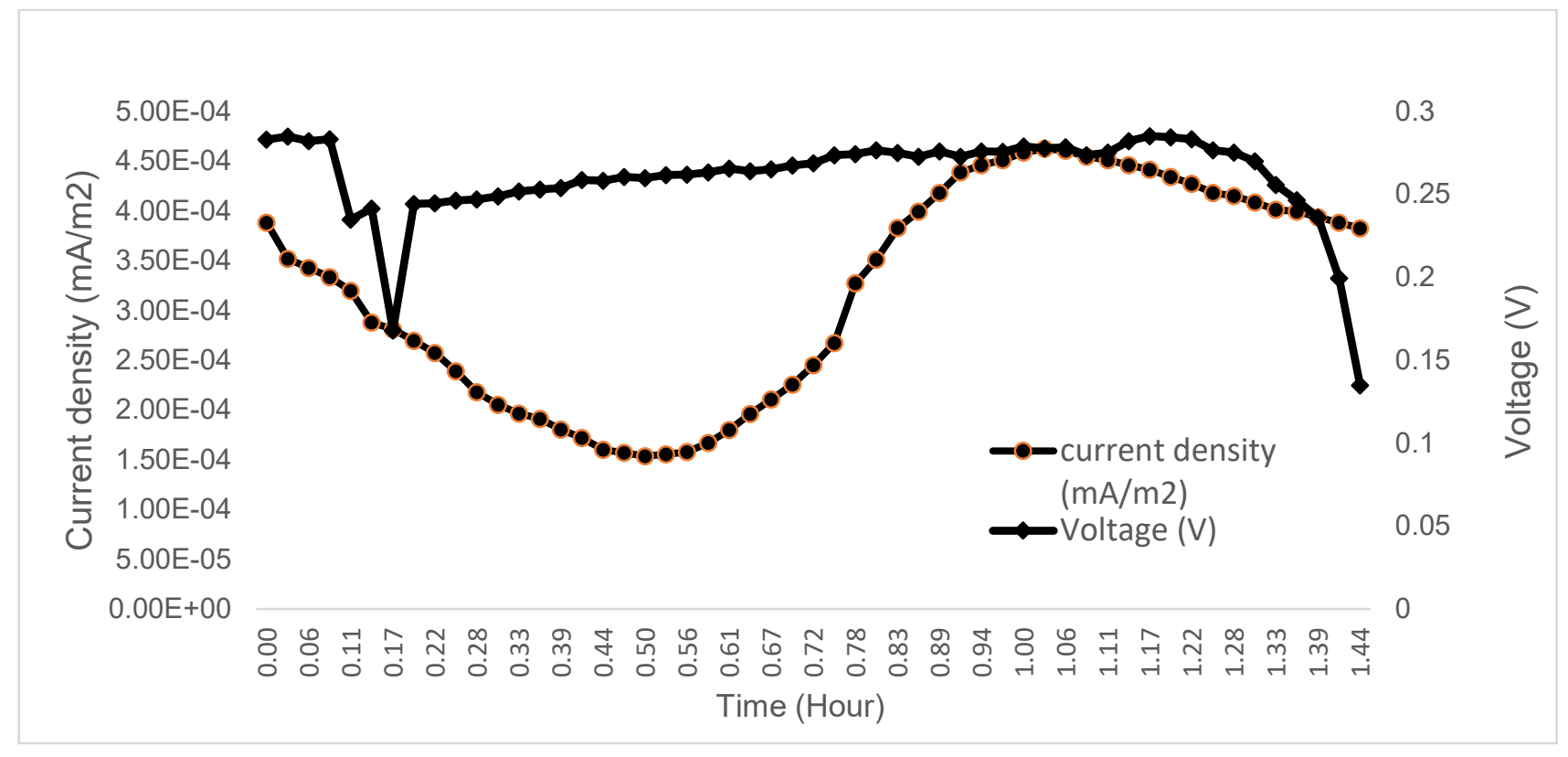

Figure 3. The voltage versus current density profile when the initial substrate concentration was $201.2 \mathrm{mg} / \mathrm{L}$ for day 1 


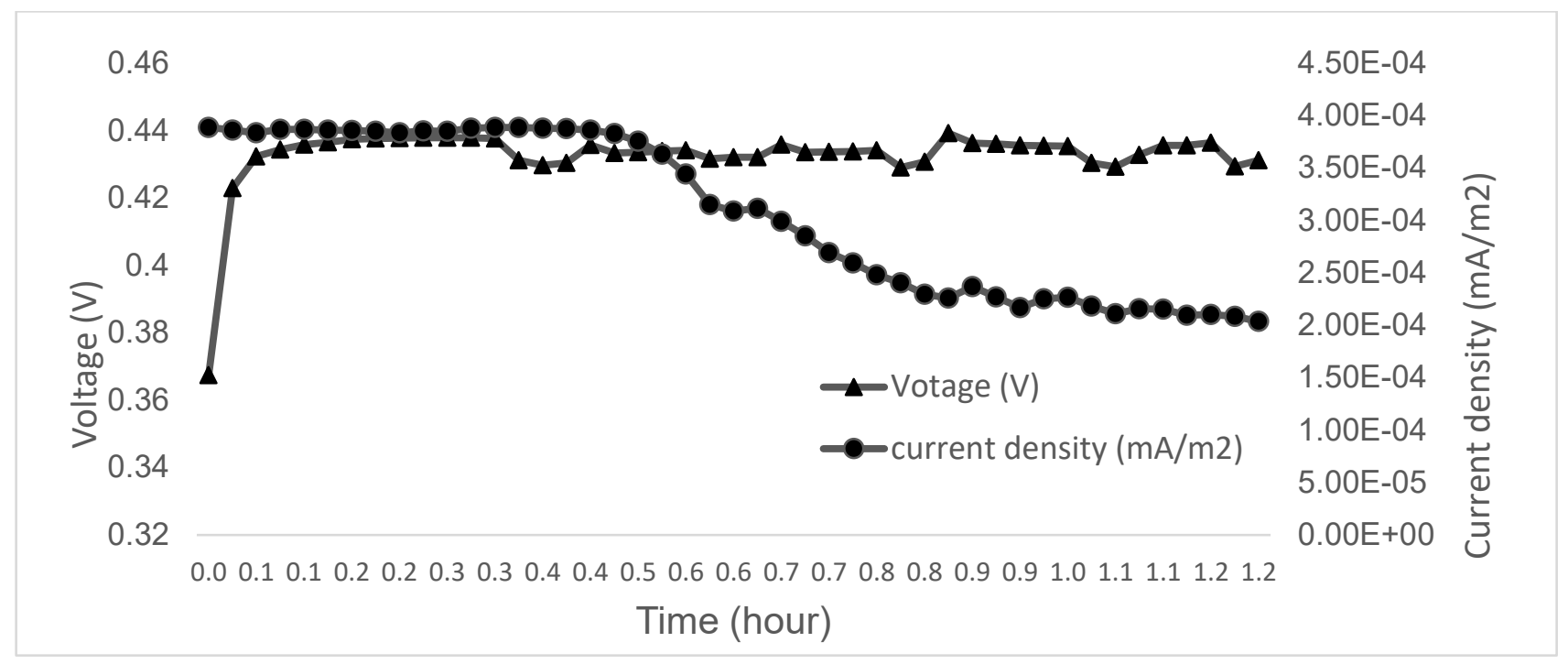

Figure 4. The voltage versus current density after MSC run for 1 day, when the initial substrate concentration $2034 \mathrm{mg} / \mathrm{L}$ (measured current and voltage continuously observed for 1 hour)

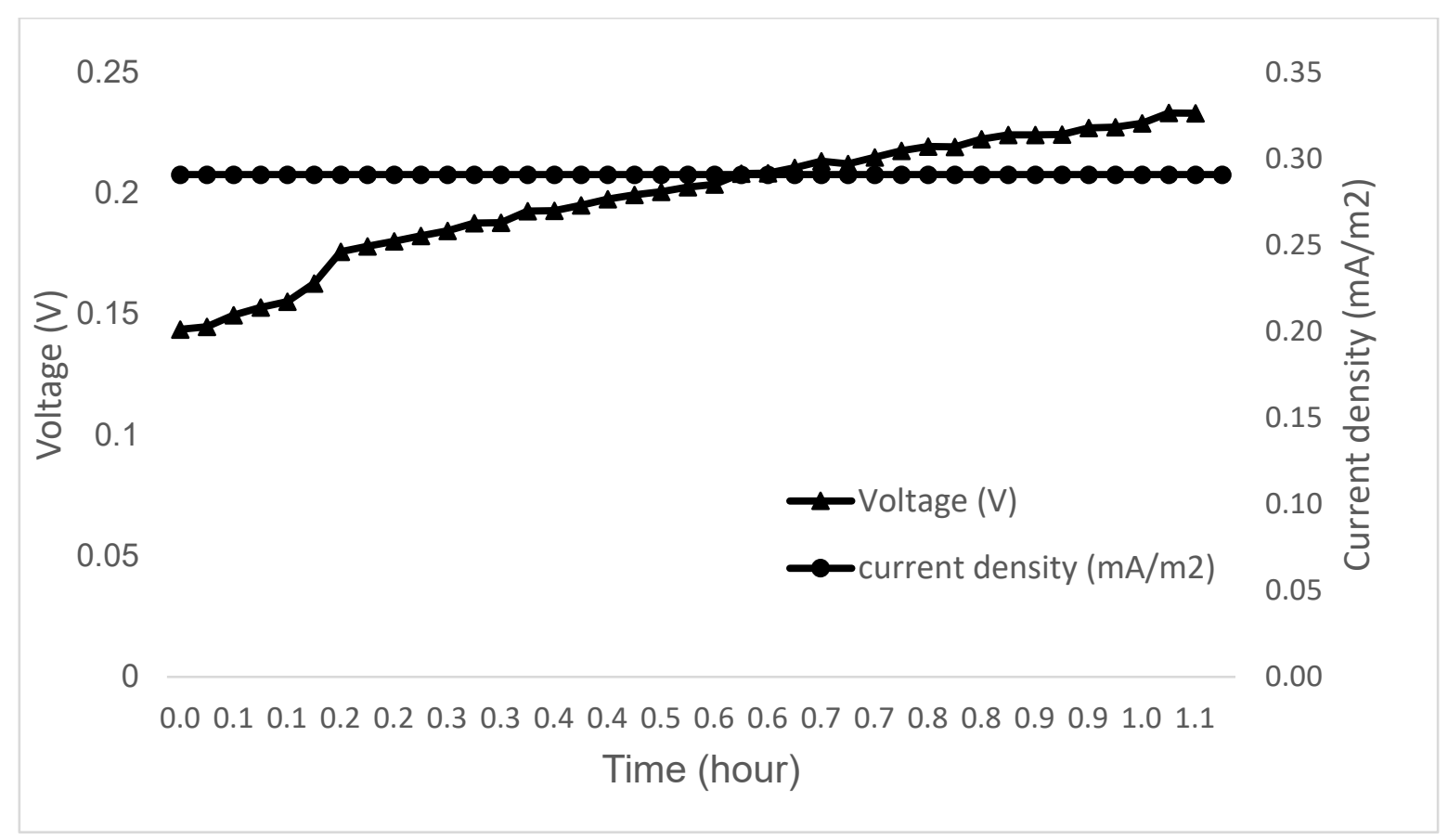

Figure 5. The voltage versus current density after MSC run for 7 day, with the initial substrate concentration $2034 \mathrm{mg} / \mathrm{L}$ (measured current and voltage continuously observed for 1 hour)

To measure the MSC performance, Coulombic Efficiency (written as \%CE), was calculated as in Min \& Logan, 2004. \%CE was described as the ratio between electricity produced (as currents) versus substrate utilization (as COD). In stage $1, \% \mathrm{CE}$ was only $0.59 \%$ while in stage
$2 \% \mathrm{CE}$ increased to $5.4 \%$. These results showed that higher substrate concentration resulted in higher electricity produced per COD consumed. At low COD, the biofilm that consisted of different types of organisms compete for substrate (Jadhav \& Ghangrekar, 2009). The heterotrophic 
microorganisms that have faster growth will outcompete slow growth microorganisms (such as G. sulfurreducence or any electroactive microorganism) (Logan \& Regan, 2006). The limited electron donor also affected the type of microorganism that growing in the anode chamber (Santoro, Arbizzani, Erable, \& Ieropoulos, 2017).

\subsection{MSC performance in terms of substrate utilization and increasing conductivity in salinity chamber}

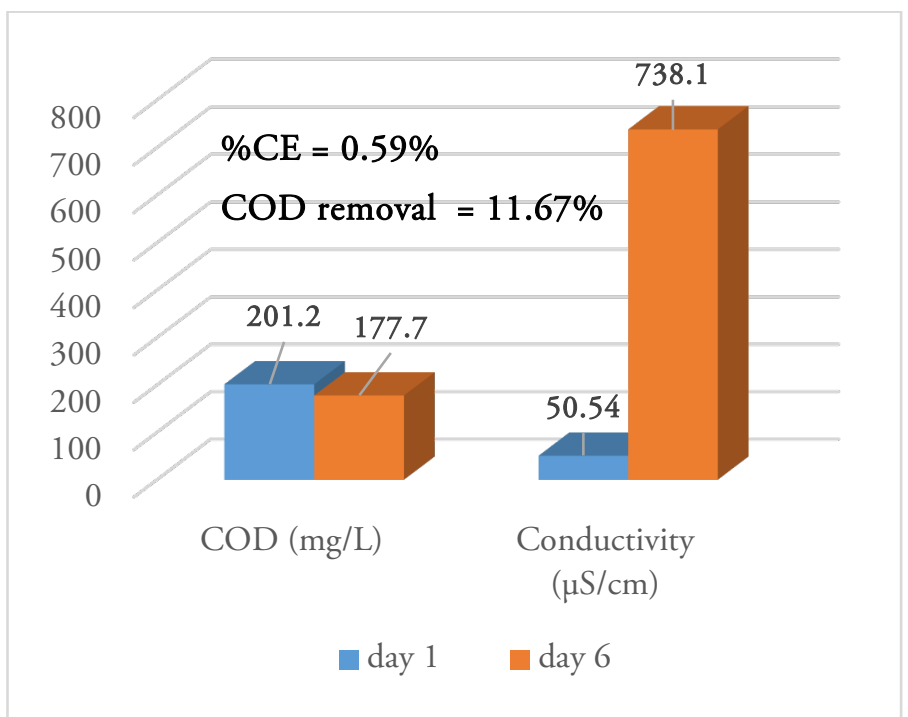

Figure 6. Substrate utilization versus conductivity increase in the first stage (when the initial substrate $201.2 \mathrm{mg} / \mathrm{L}$ )

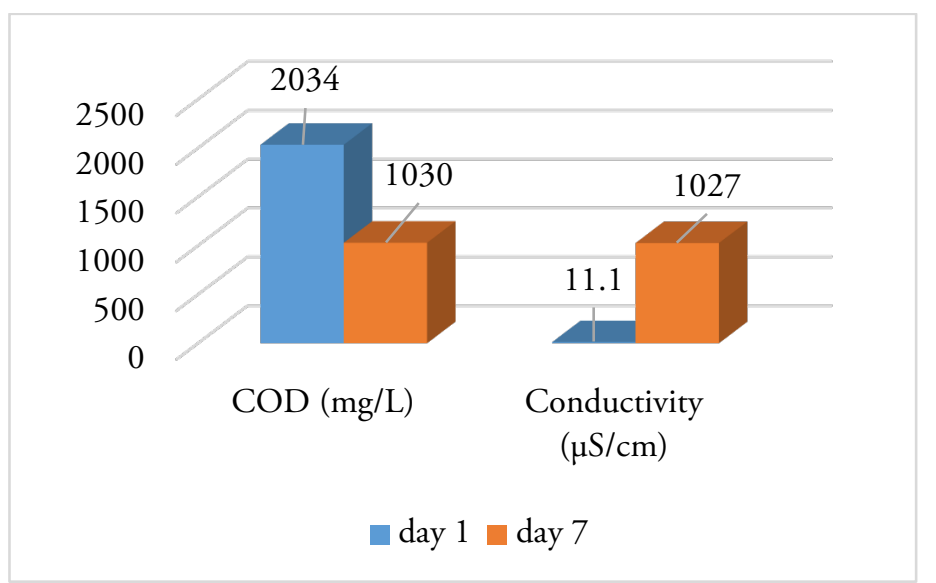

Figure 7. Substrate utilization versus conductivity increase in the second stage (when the initial substrate $2034 \mathrm{mg} / \mathrm{L}$ )
In this section, the effect of substrate utilization versus the amount of conductivity increase in the middle chamber was discussed. In stage 1, COD removal was $11.67 \%$ with corresponding conductivity increase in the salinity chamber was from $50.54 \mu \mathrm{S} / \mathrm{cm}$ to $738.1 \mu \mathrm{S} / \mathrm{cm}$ (equal to salinity $=0.36 \mathrm{ppt}$ ), and $\% \mathrm{CE}$ was $0.59 \%$. That means that the amount of substrate which can be converted into electricity was only $0.59 \%$, the rest energy derived from the oxidation of organic substrate went for driving the ions from anode to salinity chamber, resulting in the increase of conductivity. In stage 2, COD removal was $49.36 \%$ with corresponding conductivity rise in the salinity chamber was from $11.2 \mu \mathrm{S} / \mathrm{cm}$ to $1027 \mu \mathrm{S} / \mathrm{cm}$ (salinity $0.57 \% \mathrm{ppt}$ ), and $\% \mathrm{CE}$ was $5.4 \%$. \%CE gathered in this study was lower than (Zhang, Min, Huang, \& Angelidaki, 2011), because of the relatively higher initial conductivity in the anode chamber that might be hindered microorganisms metabolism (Grattieri \& Minteer, 2018). It can be concluded that the higher initial substrate concentration could lead to higher conductivity rise in the salinity chamber and the higher electricity generation. Higher COD means higher electron donor and energy, and could drive more salt ions from anode chamber into salinity chamber, and at the same time produce currents (Pant, Van Bogaert, Diels, \& Vanbroekhoven, 2010).

\section{CONCLUSION}

This study showed that the performance of a three chambers Microbial Salinity Cell (MSC) was influenced by initial substrate concentration in the anode chamber. The best performance of MSC achieved when COD was 2034 $\mathrm{mg} / \mathrm{L}$, which simultaneously produced voltage of $0.44 \mathrm{~V}$, current density of $0.29 \mathrm{~mA} / \mathrm{m}^{2}$ and \%CE of $5.4 \%$. Furthermore, conductivity concentration in the salinity chamber increased from $11.2 \mu \mathrm{S} / \mathrm{cm}$ to $1027 \mu \mathrm{S} / \mathrm{cm}$ (salinity $0.57 \% \mathrm{ppt}$ ). To improve the performance of MSC, anode polarization and shortened distance between anode and cathode should be done. For a more practical purpose of further full-scale application in order to achieve the desirable voltage or current, the MSC should be stacked. 


\section{ACKNOWLEDGEMENT}

This research was supported by KURITA-AIT Research Grant 2018 and The Centre of Industrial Pollution Prevention Technology, The Ministry of Industry, Indonesia.

\section{REFERENCES}

Aelterman, P., Rabaey, K., The Pham, H., Boon, N., \& Verstraete, W. (2006). Continuous electricity generation at high voltages and currents using stacked microbial fuel cells. Communications in Agricultural and Applied Biological Sciences, 71(1), 63-66.

Aloui, F., Khoufi, S., Loukil, S., \& Sayadi, S. (2009). Performances of an activated sludge process for the treatment of fish processing saline wastewater. Desalination, 246(1-3), 389-396. https://doi.org/10.1016/j.desal.2008.03.062

Chen, X., Liang, P., Wei, Z., Zhang, X., \& Huang, X. (2012). Sustainable water desalination and electricity generation in a separator coupled stacked microbial desalination cell with buffer free electrolyte circulation. Bioresource Technology, 119, 88-93. https://doi.org/10.1016/j.biortech.2012.05.135

Fan, Y., Hu, H., \& Liu, H. (2007). Enhanced Coulombic efficiency and power density of air-cathode microbial fuel cells with an improved cell configuration. Journal of Power Sources, 171(2), 348-354. https://doi.org/10.1016/j.jpowsour.2007.06.220

Grattieri, M., \& Minteer, S. D. (2018). Microbial fuel cells in saline and hypersaline environments: Advancements, challenges and future perspectives. Bioelectrochemistry, 120 (2018), 127-137.

Gude, V. G. (2016). Wastewater treatment in microbial fuel cells - An overview. Journal of Cleaner Production, $\quad 122, \quad 287-307$. https://doi.org/10.1016/j.jclepro.2016.02.022

Jadhav, G. S., \& Ghangrekar, M. M. (2009). Performance of microbial fuel cell subjected to variation in $\mathrm{pH}$, temperature, external load and substrate concentration. Bioresource Technology, 100(2), 717-723.

Kim, Y., \& Logan, B. E. (2013). Simultaneous removal of organic matter and salt ions from saline wastewater in bioelectrochemical systems. Desalination, 308, 115-121.

https://doi.org/10.1016/j.desal.2012.07.031

Lefebvre, O., \& Moletta, R. (2006). Treatment of organic pollution in industrial saline wastewater: A literature review. Water Research, 40(20), 3671-3682. https://doi.org/10.1016/j.watres.2006.08.027

Lefebvre, O., Tan, Z., Kharkwal, S., \& Ng, H. Y. (2012). Effect of increasing anodic $\mathrm{NaCl}$ concentration on microbial fuel cell performance. Bioresource Technology, 112, 336-340. https://doi.org/10.1016/j.biortech.2012.02.048

Logan, B. E., \& Regan, J. M. (2006). Electricity-producing bacterial communities in microbial fuel cells. Trends in Microbiology, 14(12), 512-518. https://doi.org/10.1016/j.tim.2006.10.003

Mehanna, M., Kiely, P. D., Call, D. F., \& Logan, B. E. (2010). Microbial electrodialysis cell for simultaneous water desalination and hydrogen gas production. Environmental Science and Technology, $44(24)$, 9578-9583. https://doi.org/10.1021/es1025646

Min, B., \& Logan, B. (2004). Continous Electricity Generation from DOmestic Wastewater and organic substrate in a flat Microbial Fuel Cell. Environ. Sci. Technol., 38(21), 5809-5814.

Pant, D., Van Bogaert, G., Diels, L., \& Vanbroekhoven, K. (2010). A review of the substrates used in microbial fuel cells (MFCs) for sustainable energy production. Bioresource Technology, 101(6), 1533-1543.

Qu, Y., Feng, Y., Wang, X., Liu, J., Lv, J., He, W., \& Logan, B. E. (2012). Simultaneous water desalination and electricity generation in a microbial desalination cell with electrolyte recirculation for $\mathrm{pH}$ control. Bioresource Technology, 106, 89-94. https://doi.org/10.1016/j.biortech.2011.11.045 
Santoro, C., Arbizzani, C., Erable, B., \& Ieropoulos, I. (2017). Microbial fuel cells: From fundamentals to applications. A review. Journal of Power Sources, 356,225-244.

https://doi.org/10.1016/j.jpowsour.2017.03.109
Zhang, Y., Min, B., Huang, L., \& Angelidaki, I. (2011). Electricity generation and microbial community response to substrate changes in microbial fuel cell. Bioresource Technology, 102(2), 1166-1173. https://doi.org/10.1016/j.biortech.2010.09.044. 